\title{
A physicochemical investigation of membrane fouling in cold microfiltration of skim milk
}

\author{
T. J. Tan, ${ }^{*} \dagger$ D. Wang, ${ }^{*}$ and C. I. Moraru ${ }^{* 1}$ \\ *Department of Food Science, Cornell University, Ithaca, NY 14853 \\ †Department of Biotechnology, International Islamic University Malaysia, 25200 Kuantan, Malaysia
}

\begin{abstract}
The main challenge in microfiltration (MF) is membrane fouling, which leads to a significant decline in permeate flux and a change in membrane selectivity over time. This work aims to elucidate the mechanisms of membrane fouling in cold MF of skim milk by identifying and quantifying the proteins and minerals involved in external and internal membrane fouling. Microfiltration was conducted using a $1.4-\mu \mathrm{m}$ ceramic membrane, at a temperature of $6 \pm 1{ }^{\circ} \mathrm{C}$, cross-flow velocity of 6 $\mathrm{m} / \mathrm{s}$, and transmembrane pressure of $159 \mathrm{kPa}$, for 90 min. Internal and external foulants were extracted from a ceramic membrane both after a brief contact between the membrane and skim milk, to evaluate instantaneous adsorption of foulants, and after MF. Four foulant streams were collected: weakly attached external foulants, weakly attached internal foulants, strongly attached external foulants, and strongly attached internal foulants. Liquid chromatography coupled with tandem mass spectrometry analysis showed that all major milk proteins were present in all foulant streams. Proteins did appear to be the major cause of membrane fouling. Proteomics analysis of the foulants indicated elevated levels of serum proteins as compared with milk in the foulant fractions collected from the adsorption study. Caseins were preferentially introduced into the fouling layer during MF, when transmembrane pressure was applied, as confirmed both by proteomics and mineral analyses. The knowledge generated in this study advances the understanding of fouling mechanisms in cold MF of skim milk and can be used to identify solutions for minimizing membrane fouling and increasing the efficiency of milk MF.
\end{abstract}

Key words: membrane fouling, cold microfiltration, protein fouling

Received January 17, 2014.

Accepted April 7, 2014.

${ }^{1}$ Corresponding author: cim24@cornell.edu

\section{INTRODUCTION}

Microfiltration (MF) has gained significant attention in recent years as a processing method for the removal of microorganisms from milk. Microfiltration of milk using large-pore-size membranes has been shown to be very efficient in removal of bacteria, spores, and somatic cells from skim milk, while allowing almost complete permeation of other milk components (Saboya and Maubois, 2000; Te Giffel and Van der Horst, 2004; Fritsch and Moraru, 2008). Bacteria spores and somatic cells present in raw milk are not affected by the HTST heat treatment used in the processing of most dairy products, whereas they can be physically removed by MF. If not removed or killed, spores can compromise the quality and shelf life of milk and other dairy products, such as milk powder and cheese (GesanGuiziou, 2010). At the same time, high SCC can lead to increased proteolytic and lipolytic activity in milk, thus compromising the flavor, texture, and shelf life of dairy foods (Azzara and Dimick, 1985; Verdi and Barbano, 1988; Ma et al., 2000; Te Giffel and Van der Horst, 2004).

The main challenge in milk MF is membrane fouling, which leads to a significant decline in the permeate flux and undesirable changes of membrane selectivity (Guerra et al., 1997). Membrane fouling is caused by the specific physicochemical interactions between the milk components and the membrane. Fouling can occur both because of the deposition of rejected solutes and particles on the membrane surface (external fouling) and to the constriction of pores by feed particles (internal fouling). Particles with diameters much smaller than the membrane pore typically cause pore constriction, those with a diameter comparable to the membrane pore may cause pore blocking, and particles larger than the pores can be retained on the membrane surface and cause cake formation (Fane and Chang, 2009).

Proteins are considered a major contributor to fouling in membrane separation of dairy streams, both due to their interaction with the membrane and due to protein-protein interactions, which lead to formation of agglomerates (James et al., 2003). Brans et al. (2004) 
proposed that in skim milk, MF $\mathrm{CN}$ micelles and $\mathrm{CN}$ aggregates lead to pore blockage, whereas serum proteins cause adsorption and in-pore fouling. Le Berre and Daufin (1998) concluded that CN are the main factor limiting the flux in MF of milk with a 0.1- $\mu \mathrm{m}$-pore-size membrane. Nonetheless, several studies reported that serum proteins and their aggregates are almost entirely responsible for membrane fouling in MF of dairy fluids using membranes of sub-micrometric pore sizes (Tong et al., 1988; Kelly and Zydney, 1997; MourouzidisMourouzis and Karabelas, 2006). Regarding the role of individual serum proteins, it was reported that $\beta$-LG contributes to fouling because of its tendency for selfassociation and the formation of dimers and octamers (Kelly and Zydney, 1997; Mourouzidis-Mourouzis and Karabelas, 2006), whereas $\alpha$-LA has the ability to strongly bind $\mathrm{Ca}^{2+}$ (Stuart et al., 1986; Anderson et al., 1997), which results in a calcium-mediated salt bridging between $\alpha$-LA and the membrane.

Minerals, particularly calcium phosphate, are also considered as one of the leading causes of membrane fouling and flux decline in membrane separation of dairy streams (Hanemaaijer et al., 1989; Gesan et al., 1993). Calcium phosphate precipitate can form deposits on and within the membrane, whereas divalent cations $\left(\mathrm{Ca}^{2+}\right)$ facilitate protein-protein and protein-membrane interactions (Rice et al., 2009). This is particularly pronounced at high temperatures, which promote precipitation of calcium phosphate. Low temperatures $\left(<10^{\circ} \mathrm{C}\right)$ are conducive of micelle disintegration and thus dispersion of calcium out of the $\mathrm{CN}$ micelle, also leading to mineral-based fouling.

It has been also suggested that microbial cells can cause fouling by pore blockage in large-pore MF (Brans et al., 2004). Indeed, in the study by Blanpain-Avet et al. (2011) spores and vegetative cell clusters were observed on the membrane surface after the MF of a suspension of Bacillus cereus spores with a $0.45-\mu \mathrm{m}$ ceramic membrane, performed at a cross-flow velocity of $4 \mathrm{~m} / \mathrm{s}$. However, Fritsch and Moraru (2008) did not observe any bacteria cells or spores in scanning electron microscope images of a fouled ceramic membrane used in cold MF of skim milk using a 1.4- $\mu$ m-pore ceramic membrane. This may have been be due to the high cross-flow velocity $(7 \mathrm{~m} / \mathrm{s})$ used in their study, which possibly prevented the deposition of microorganisms onto the membrane.

Most of the studies mentioned above refer to fouling in small-pore MF (using sub-micrometric pore diameters) of dairy streams. Very little data exist regarding the mechanisms of membrane fouling in large-pore MF of milk, particularly when the process is conducted at low temperatures. As the interest in cold MF of milk is increasing, elucidation of fouling mechanisms could provide insights that would help the development of effective solutions to improve the flux and separation efficiency of this process. The objective of this work was to investigate the mechanism of membrane fouling in large-pore, cold MF of skim milk, focusing on the role of proteins and minerals in external and internal fouling during large-pore MF for microbial removal.

\section{MATERIALS AND METHODS}

\section{MF Setup and Experiments}

A pilot-scale experimental MF unit that included a feed tank with a capacity of $189 \mathrm{~L}$ connected to a variable-speed centrifugal pump, a tubular heat exchanger, a flow meter, and a tubular ceramic membrane placed inside a stainless steel housing was used. The membrane, of Tami design (GEA Filtration, Hudson, WI), had a nominal pore size of $1.4 \mu \mathrm{m}$, a length of 1,200 $\mathrm{mm}$, an outside diameter of $25 \mathrm{~mm}, 23$ internal channels with a hydraulic diameter of $3.5 \mathrm{~mm}$ each, and a total membrane area of $0.35 \mathrm{~m}^{2}$. Data acquisition ports were used for collecting the pressure, temperature, and flow rate data. The transmembrane pressure (TMP) was calculated as follows:

$$
\mathrm{TMP}=\frac{\left(P_{\mathrm{i}}+P_{\mathrm{o}}\right)}{2}-P_{\mathrm{p}},
$$

where $P_{\mathrm{i}}$ is the feed inlet pressure, $P_{\mathrm{o}}$ is the retentate outlet pressure, and $P_{\mathrm{p}}$ is the permeate pressure.

The permeate flux was obtained gravimetrically using an electronic scale connected to the data acquisition system. The permeate flux, $J\left(\mathrm{~L} / \mathrm{m}^{2} \mathrm{~h}\right)$, was calculated according to the equation

$$
J=\frac{M}{A \times t \times \rho},
$$

where $M$ is the permeate weight $(\mathrm{kg}), A$ is the membrane surface area $\left(\mathrm{m}^{2}\right), t$ is time $(\mathrm{h})$, and $\rho$ is the permeate density at the operating temperature $\left(\mathrm{kg} / \mathrm{m}^{3}\right)$.

A total of $117 \mathrm{~kg}$ of raw skim milk from the Cornell Dairy Plant (Ithaca, NY) was added to the feed tank. The pump was turned on at low velocity for $20 \mathrm{~s}$ to flush out any water that remained in the membrane system after water-flux measurement. After another 70 $\mathrm{s}$, the pump speed was adjusted to a cross-flow velocity (v) of $6.0 \mathrm{~m} / \mathrm{s}$, a constant transmembrane pressure of $159 \mathrm{kPa}$ (23 psi) was achieved, and permeate flux data collection was initiated. The MF process was conducted at a temperature of $6 \pm 1^{\circ} \mathrm{C}$. To maintain temperature control during $\mathrm{MF}$, the milk was passed through a 
countercurrent tubular heat exchanger that used chilled water as the cooling medium. For every $20 \mathrm{~kg}$ of permeate collected, $20 \mathrm{~kg}$ of raw skim milk was added back into the feed tank to ensure a constant milk level in the feed tank. The duration of a MF run was $90 \mathrm{~min}$.

Chemical Cleaning of the Membrane. After each use, a complete chemical cleaning cycle of the membrane was carried out. The cleaning procedure consisted of a reverse-osmosis (RO) water rinse for $10 \mathrm{~min}$, followed by alkaline cleaning with Ultrasil-25 (Ecolab Inc., St. Paul, MN) at a concentration of $16 \mathrm{~mL} / \mathrm{L}$ at $80^{\circ} \mathrm{C}$ for 30 min, a second $\mathrm{RO}$ water rinse for $10 \mathrm{~min}$ or until neutrality (checked with $\mathrm{pH}$ strips), acid cleaning with $\mathrm{HNO}_{3}$ solution at a concentration of $5 \mathrm{~mL} / \mathrm{L}$ at $50^{\circ} \mathrm{C}$ for $20 \mathrm{~min}$, and a final $\mathrm{RO}$ water rinse for $10 \mathrm{~min}$ or until neutral $\mathrm{pH}$ was reached. At the end of each experiment, the membrane housing was disassembled and the membrane was taken out, air dried, and stored dry until further use.

Water-Flux Measurement. The membrane cleanliness was determined before each MF run by measuring the water flux. The water flux was measured for $3 \mathrm{~min}$ using $\mathrm{RO}$ water at $20^{\circ} \mathrm{C}$ and an average transmembrane pressure of $83 \mathrm{kPa}(12 \mathrm{psi})$.

\section{Physical Characterization of Membrane Fouling}

Particle-Size Analyses of Membrane Foulants. To gain an insight into the physical state of the membrane foulants, a sample of the fouling layer was collected by gently brushing the membrane surface, to preserve its physical structure as much as possible. First, MF was conducted for $90 \mathrm{~min}$ to deposit sufficient fouling material onto the membrane. The membrane was then taken out carefully from its housing and placed vertically to drain out the skim milk residue, and then it was rinsed with $\mathrm{RO}$ water until the rinse solution was clear. This rinsing step was repeated 3 times, and each rinse solution was collected separately. A clean nylon brush of 2-mm diameter and fine bristles was prewetted with $\mathrm{RO}$ water and used to gently scrub the membrane channels to recover the fouling-layer material deposited onto the membrane surface. After brushing the brush was cut into small pieces, which were then rinsed with $\mathrm{RO}$ water to recover the fouling material from the bristles.

The rinse containing the fouling material was evaluated for particle-size distribution by dynamic light scattering, using a Brookhaven 90Plus Nanoparticle Size Analyzer (Brookhaven Instruments Corp., Holtsville, NY). For comparison, the particle-size distribution of the skim milk feed and the MF permeate were also determined. The particle-size measurements were conducted at room temperature (around $20^{\circ} \mathrm{C}$ ), a fixed
90 degree angle, a wavelength of $658 \mathrm{~nm}$, and a variable refractive index. Data collection and analysis was performed using the BIC software (Brookhaven Instruments Corp.). The software contains a Dust Filter algorithm that improves the quality of the measurements by rejecting data affected by random scattering from air bubbles or dust particles. The dust-filter cut-off parameter was set at 30 , which is the optimal value suggested by the manufacturer. Each measurement consisted of 8 subsequent individual runs of 30 -s duration.

Zeta-Potential Measurements. The zeta potential of skim milk and ceramic membrane particles was determined using a 90Plus Nanoparticle Size Analyzer (Brookhaven Instruments Corp.) fitted with the ZetaPlus option. The measurement consisted of 30 cycles per run, with an intercycle delay of $5 \mathrm{~s}$. Skim milk was diluted with deionized water before the measurement. Ceramic particles were scrubbed from the active layer of both a new membrane and an old membrane (clean, but previously used in skim milk MF experiments). The ceramic particles were suspended in deionized water before zeta-potential measurement. For both skim milk and the suspension of ceramic particles, the dilution was adjusted to achieve the recommended instrument count rate of 300 to $350 \mathrm{kcps}$. Zeta-potential measurements were performed over a range of $\mathrm{pH}$ ( $\mathrm{pH} 3$ to 7 ). The $\mathrm{pH}$ of the solution was adjusted by adding $1.0 \mathrm{M}$ $\mathrm{HCl}$ (Fisher Scientific, Chicago, IL) to decrease the $\mathrm{pH}$ or 1.0 $M \mathrm{NaOH}$ (Fisher Scientific) to increase the pH. The $\mathrm{pH}$ measurements were conducted with a Fisher Scientific Accumet Excel XL25 pH/mV/Temperature/ ISE Meter (Fisher Scientific), at room temperature.

Contact-Angle Measurements. Hydrophobicity of the active layer of the membrane surface was evaluated by performing contact-angle measurements by the sessile drop method using a Rame-Hart 500 goniometer (Rame-Hart Inc., Succasunna, NJ). Briefly, 15- $\mu$ L droplets of Milli-Q ultrapure water were allowed to contact the surface, and advancing angles were measured. All measurements were performed in triplicate.

Imaging of Fouling Materials Using Scanning Electron Microscopy. Following a MF run, the fouled ceramic membrane was removed from its stainless steel housing and the residual skim milk drained out. One end of the membrane was frozen by dipping it into liquid nitrogen and then freeze fractured. Small pieces of membrane (about 5 by $5 \mathrm{~mm}$ ) were collected, then freeze-dried overnight, and sputter coated with a 60:40 mixture of $\mathrm{Au}$ and Pd using a Denton Vacuum Desk II Cold Sputter Etch Unit (Denton Vacuum, Moorestown, NJ). An exposure time of $30 \mathrm{~s}$ was used, which yielded about $10 \mathrm{~nm}$ of coating. The sputter coated samples were then viewed with a Leica Stereoscan 440 Scanning Electron Microscope (Leica Cambridge Ltd., 


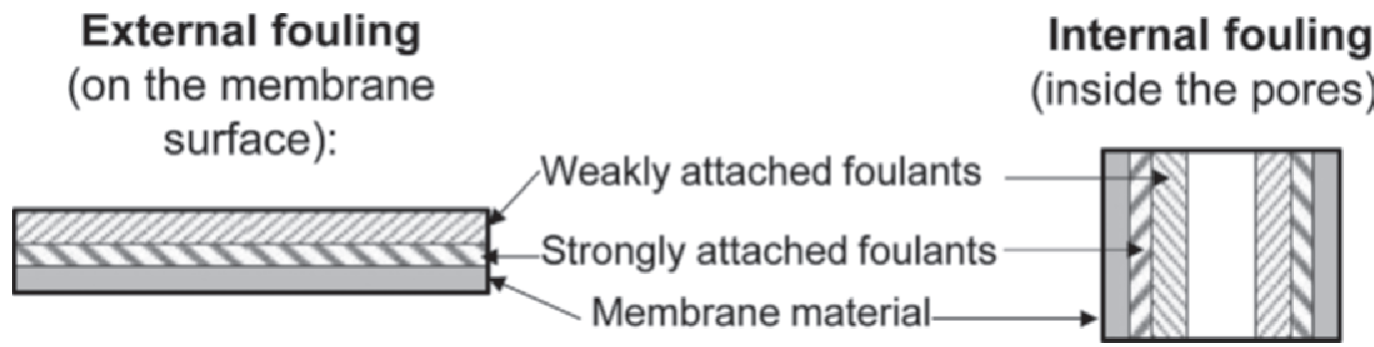

Figure 1. Schematic indicating the location of the weakly and strongly attached membrane foulants.

Cambridge, UK), at the Cornell Center for Materials Research (Ithaca, NY).

\section{Chemical Characterization of Membrane Fouling}

Immediately after a 90-min MF run, the skim milk remaining in the feed tank was drained, and the MF unit was flushed with $\mathrm{RO}$ water at $6 \pm 1^{\circ} \mathrm{C}$ for $15 \mathrm{~s}$, to wash out the milk residue from the system. The membrane was then taken out of the MF unit and positioned vertically for $10 \mathrm{~min}$ to drain out the residual mixture of skim milk and RO water from the membrane channels. The MF unit was reassembled without the membrane and cleaned with $180 \mathrm{~L}$ of RO water for 2 min at $20^{\circ} \mathrm{C}$ and a pump speed of $1,710 \mathrm{rpm}$ to remove the residual skim milk from the MF unit. After this rinse step, the membrane was installed back into the unit, and the internal and external foulants were collected. The location of the foulants is shown schematically in Figure 1.

Collection of Weakly Attached Foulants. Reverse-osmosis water rinsing of the membrane was carried out first to collect the weakly attached external foulants $\left(\mathbf{W}_{\mathrm{e}}\right)$ and the weakly attached internal foulants $\left(\mathbf{W}_{\mathbf{i}}\right)$. Twenty kilograms of RO water was added to the feed tank. Reverse-osmosis water rinsing was first conducted with the permeate outlet fully closed and the retentate outlet fully opened. The RO water rinse was performed for $5 \mathrm{~min}$ at $20^{\circ} \mathrm{C}$, at a pump speed of $1,710 \mathrm{rpm}$, corresponding to a cross-flow velocity of $3.1 \mathrm{~m} / \mathrm{s}$ and a flow rate of $40.9 \mathrm{~L} / \mathrm{min}$. The rinse water collected in this manner contained the external foulants weakly attached to the membrane surface. The remaining rinsing solution was drained from the $\mathrm{MF}$ unit, after which the membrane was flushed with $\mathrm{RO}$ water at $20^{\circ} \mathrm{C}$ for $15 \mathrm{~s}$ to wash out the residual rinsing solution. The membrane was then removed from the MF unit and positioned vertically for $10 \mathrm{~min}$, to drain out the residual RO water in the membrane. The MF unit was reassembled without the membrane, cleaned with $\mathrm{RO}$ water for $2 \mathrm{~min}$ at $20^{\circ} \mathrm{C}$, at a pump speed of $1,710 \mathrm{rpm}$, after which the membrane was installed back into the unit.
Next, RO water rinsing was conducted with the permeate outlet fully opened and the retentate outlet fully closed to collect the internal foulants weakly attached to the internal structure of the membrane. Another $20 \mathrm{~kg}$ of $\mathrm{RO}$ water was added to the feed tank, and $\mathrm{RO}$ water rinsing was performed for $5 \mathrm{~min}$ at $20^{\circ} \mathrm{C}$, at a pump speed of $1,710 \mathrm{rpm}$, corresponding to a flow rate of $1.9 \mathrm{~L} / \mathrm{min}$. In this setting no flow existed along the membrane, only flow through the membrane. The weakly attached internal foulants sample was collected, and the remaining rinsing solution was drained. Next, the membrane was flushed again with $\mathrm{RO}$ water at $20^{\circ} \mathrm{C}$ for $15 \mathrm{~s}$ to wash out the residual rinsing solution. After that, the membrane was taken out from the MF unit and positioned vertically for $10 \mathrm{~min}$ to drain out the residual $\mathrm{RO}$ water in the membrane. The MF unit was reassembled without the membrane and cleaned with $\mathrm{RO}$ water for $2 \mathrm{~min}$ at $20^{\circ} \mathrm{C}$, at a pump speed of $1,710 \mathrm{rpm}$. After that, the membrane was reinstalled into the unit.

Collection of Strongly Attached Foulants. To extract the foulants strongly attached to the membrane, the same procedures as described above were employed, with the difference that hot water $\left(70^{\circ} \mathrm{C}\right)$ was used instead of room temperature water. Thirty kilograms of pressurized hot RO water was used for collection of strongly attached external foulants $\left(\mathbf{S}_{\mathrm{e}}\right)$ and $20 \mathrm{~kg}$ of pressurized hot RO water for collection of strongly attached internal foulants $\left(\mathbf{S}_{\mathbf{i}}\right)$. Each pressurized hot water extraction was carried out for 10 min at $70^{\circ} \mathrm{C}$ at a pump speed of 3,000 rpm (corresponding to a flow rate of $81.4 \mathrm{~L} / \mathrm{min}$ and a cross-flow velocity of 6.1 $\mathrm{m} / \mathrm{s}$ ) for collecting external foulants and a flow rate of $9.8 \mathrm{~L} / \mathrm{min}$ for collecting the internal foulants.

Adsorption Study. A study was also carried out to evaluate the instantaneous adsorption of milk components onto the membrane before the application of transmembrane pressure. For this, the tubular ceramic membrane was wrapped with 2 layers of parafilm, to seal the permeate side of the membrane. The sealed membrane was placed inside a heavy duty poly tubing (Uline, Pleasant Prairie, WI) and submersed in $1 \mathrm{~L}$ of raw skim milk at $6^{\circ} \mathrm{C}$ for $5 \mathrm{~min}$. After $5 \mathrm{~min}$, the mem- 
brane was taken out from the poly tubing and rinsed with $1 \mathrm{~L}$ of $\mathrm{RO}$ water vertically, from the membrane inlet to the outlet, and the rinse drained. A second rinse was performed from the outlet to the inlet. After that, the parafilm was removed, and the membrane was positioned vertically for 5 min to drain out the residual rinsing solution. The drained membrane was placed inside a new poly tubing bag and submersed in $1 \mathrm{~L}$ of $\mathrm{RO}$ water. After $10 \mathrm{~min}$, the membrane was taken out from the poly tubing and positioned vertically for $5 \mathrm{~min}$ to drain out the water. Any foulants that remained in the membrane at this point were assumed to be attached to the membrane due to adsorption. The internal and external adsorption foulants were then collected from the membrane using the procedure outlined above. The foulant collection described above was conducted in triplicate, in 3 different experimental runs, and all collected samples were submitted for protein and mineral analyses.

Quantification of Proteins Using the Bradford Method. Because the concentration of proteins in the foulant fractions was expected to fall below the sensitivity limit of the Kjeldahl method, the protein content in the external and internal foulants was quantified using the micro Bradford assay (Bradford, 1976). The Bradford method is based on the principle that Coomassie Brilliant Blue G-250 changes color from reddish to bluish when it binds to protein, and the absorption maximum of the dye is shifted from 465 to $595 \mathrm{~nm}$. The change in the absorbance at $595 \mathrm{~nm}$ is proportional to the protein concentration in the sample. One milliliter of samples containing foulants and $1 \mathrm{~mL}$ of protein standard of known concentration were mixed with 1 $\mathrm{mL}$ of the Bradford reagent. Absorbance at $595 \mathrm{~nm}$ was read against a reagent blank, and the protein content in the sample was estimated from the standard curve.

The Coomassie Brilliant Blue binds specifically to the arginine residue. The amino acid composition of different proteins may lead to different absorbanceconcentration curves, which gives significant proteinto-protein variation when using the Bradford method. Therefore, the best protein to use as a standard would be a purified preparation of the protein being assayed. Because the samples evaluated in this work contained a mixture of proteins, 3 different milk proteins were tested to evaluate their suitability as a standard: BSA, $\alpha-C N$, and $\beta$-LG (Sigma-Aldrich Co., St. Louis, MO). For all the proteins a good linear relationship between absorbance and protein concentration was obtained, although the slopes were different for each of the proteins. The Bradford method was further calibrated with the Kjeldahl method using evaporated milk of different concentration. This calibration indicated that $\beta$-LG provided the most accurate estimation of protein

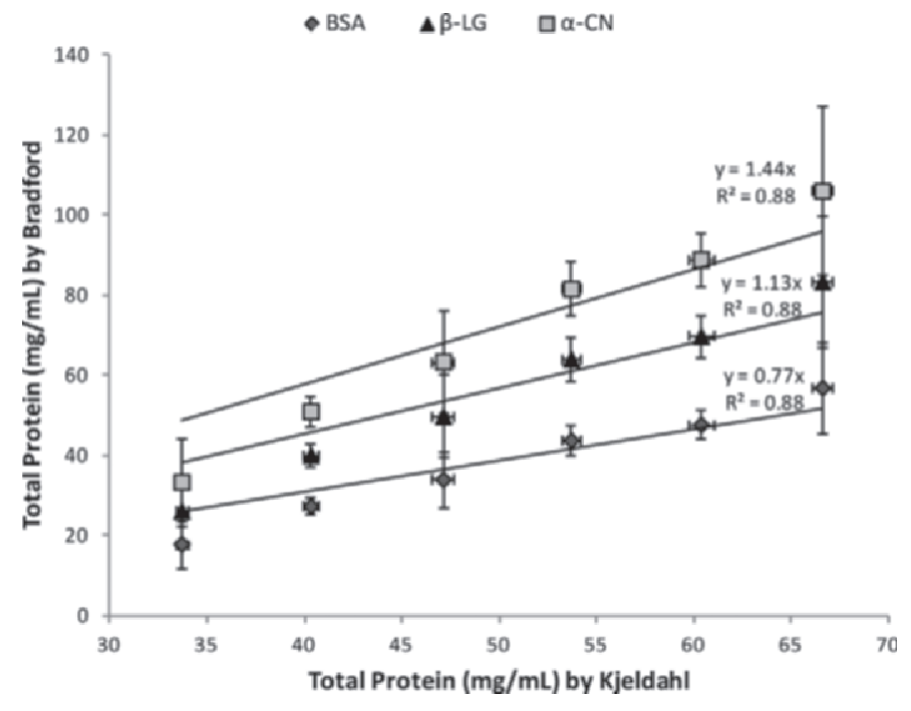

Figure 2. Correlation of protein content obtained by the Bradford and Kjeldahl methods. Error bars represent one standard deviation $(\mathrm{n}=3)$.

concentration using the Bradford method among the proteins tested, because the slope of the Bradford protein concentration versus Kjeldahl protein concentration curve for this protein was closest to one (Figure 2). Hence, $\beta$-LG was used as a standard when quantifying the protein content in the foulant samples by Bradford method.

Identification and Relative Quantification of Proteins. Milk proteins present in the various foulant fractions were identified using liquid chromatography coupled with tandem mass spectrometry (LC-MS/ MS) at the Cornell University Proteomics and Mass Spectrometry Core Facility (Ithaca, NY), following the procedure described by Sauer and Moraru (2012). This method uses a 4-step process: protein digestion, protein separation, MS analysis of the digest fragments (mostly tryptic peptides), and matching the observed peptides to those in a protein database (O'Donnell et al., 2004). Prior to LC-MS/MS analysis, the collected foulant samples were freeze-dried (FreeZone 4.5 freeze drying system, Labconco, Kansas City, MO). The freeze-dried foulants were dissolved in $1.0 \mathrm{~mL}$ of $3 \mathrm{M}$ guanidine hydrochloride, after which disulfide bonds were reduced with 16 $\mathrm{m} M$ tris (2 carboxyethyl)phosphine during incubation at $60^{\circ} \mathrm{C}$ for $1 \mathrm{~h}$. The solution was then treated with $42 \mathrm{mM}$ iodoacetamide for $1 \mathrm{~h}$ in the dark to alkylate cysteine residues and incubated with $26 \mathrm{~m} M$ dithiothreitol for $10 \mathrm{~min}$, after which samples were diluted with $100 \mathrm{mM}$ Tris buffer for $\mathrm{pH}$ adjustment. Sequencing-grade trypsin of $40 \mathrm{ng} / \mu \mathrm{g}$ concentration was added to the solution to achieve a ratio of trypsin to protein of about 1:10, and the solution was then incubated overnight at $37^{\circ} \mathrm{C}$. The 
resulting tryptic-digested peptides were diluted in $1 \%$ formic acid/10\% acetonitrile solution. The samples were desalted and separated on a C18 RP-HPLC column, connected in-line to a triple quadrupole linear ion trap mass spectrometer 4000 Q Trap equipped with a Turbo Ion Spray Head ion source (Applied Biosystems, Foster City, CA). The spray voltage was $2.0 \mathrm{kV}$ and was used in positive ion mode. Nitrogen was used as the collision gas. In information-dependent acquisition analysis, after each survey scan for mass-to-charge $(\boldsymbol{m} / \boldsymbol{z}) 375$ to $\mathrm{m} / \mathrm{z}$ 1,600 and an enhanced resolution scan, the 3 highest intensity ions with multiple charge states were selected for MS/MS analysis. Rolling collision energy based on different charge states and $\mathrm{m} / z$ values was applied to obtain optimal MS/MS spectra of the detected ions.

The identification and relative quantification of proteins was conducted using multiple reaction monitoring approach. The sequential selection of a target peptide precursor ion was carried out in the Q1 mass analyzer, while monitoring a characteristic fragment ion in the Q3 mass analyzer after fragmentation in the collision cell Q2 (Ebhardt et al., 2012; Zhang et al., 2012; Picotti et al., 2013).

The milk proteins $\alpha_{\mathrm{s} 1^{-}} \mathrm{CN}, \alpha_{\mathrm{s} 2^{-}} \mathrm{CN}, \beta-\mathrm{CN}, \kappa-\mathrm{CN}$, $\alpha-L A, \beta-L G, B S A$, and lactotransferrin were identified in the foulant streams. The name of the identified unique tryptic-digested peptides, designated with Pep1 or Pep2 or Pep3 after the name of the proteins where the peptides originate from, the peptide sequences, and their mass-to-charge ratios as well as retention times are listed in Table 1. The relative quantification of the peptide, and therefore of the protein from which it originates, was performed by calculating the ratio of the peak area of the peptide to the peak area of the internal standard. Apomyoglobin, a protein that does not naturally occur in bovine milk, was used as the internal standard (Sauer and Moraru, 2012). The peptide with the highest response within each protein was selected and analyzed statistically for relative quantification.

Mineral Composition of Foulants. The mineral composition of the foulants was analyzed at Dairy One Forage Analysis Laboratory (Ithaca, NY). Calcium, phosphorus, magnesium, potassium, and sodium were identified and quantified using an Inductively Coupled Plasma Radial Spectrophotometer, whereas chlorine was identified and quantified by potentiometric titration (Sauer and Moraru, 2012). Triplicate mineral analyses were conducted for the foulants collected from each MF experiment and adsorption study.

\section{Statistical Analysis of Data}

All foulant collection experiments for chemical characterization and foulant chemical analyses were carried out in triplicate. To determine statistical differences between treatments, data was analyzed using ANOVA with the statistical software package JMP Pro 10.0.0 (SAS Institute Inc., Cary, NC). The Tukey-Kramer honestly significant difference test was used to determine significant differences between means at $5 \%$ level of probability.

\section{RESULTS AND DISCUSSION}

\section{A Physical Evaluation of Membrane Fouling}

As seen in Figure 3, the permeate flux during cold MF of skim milk had a rapid decline in the first minutes of the process, followed by a slower yet steady decline for the 90-min duration of the run. This drop in flux is typical for membrane filtration processes and is attributed to membrane fouling (Fritsch and Moraru, 2008).

Scanning electron microscope imaging of a piece of ceramic membrane sampled immediately after cold MF of skim milk showed the presence of a dense, gel-like layer, both on the membrane surface and in its internal structure (Figure 4). This layer is visibly obstructing the membrane porous structure and was likely the cause for the flux decay. The present study focuses on elucidating both the structure and the composition of this fouling layer.

A comparison of the particle-size distribution between the fouling layer gently brushed from the membrane surface, skim milk, and the MF permeate was conducted. Skim milk contained particles in the 10 to 2,000 $\mathrm{nm}$ range (Figure 5a). Based on general knowledge about milk components and on the study by Beliciu and Moraru (2009), the particles in skim milk correspond to the following classes: serum proteins ( $\mathrm{nm}$ to tens of $\mathrm{nm}$ size range); $\mathrm{CN}$ micelles (tens to hundreds of $\mathrm{nm}$ ); and a combination of residual fat globules, bacteria, and somatic cells (particles with diameters from 500 to 2,000 nm). According to Figure 5b, the fouling layer had a similar particle size distribution as skim milk, with the exception of missing particles larger than 1,000 $\mathrm{nm}$. Most likely, these were residual fat globules, bacteria, and somatic cells, which were washed away into the retentate stream by the turbulent flow in the feed channel. Interestingly, the permeate contained only particles of diameter smaller than 200 $\mathrm{nm}(0.2 \mu \mathrm{m}$; Figure $5 \mathrm{c})$. The fact that particles larger than $0.2 \mu \mathrm{m}$ were completely rejected by the $1.4-\mu \mathrm{m}$ membrane is a clear indication that the selectivity of the membrane was drastically affected by the fouling layer, which acted as the de facto separation barrier in the MF process.

The formation of the fouling layer can occur (1) instantaneously, due to physicochemical (electrostatic, 
Table 1. Identified peptide names, peptide sequences, charge $(z)$, mass-to-charge ratio $(\mathrm{m} / z)$ values in Q1 and Q3 mass analyzer, and retention times (RT) for the milk proteins identified in the different foulant streams

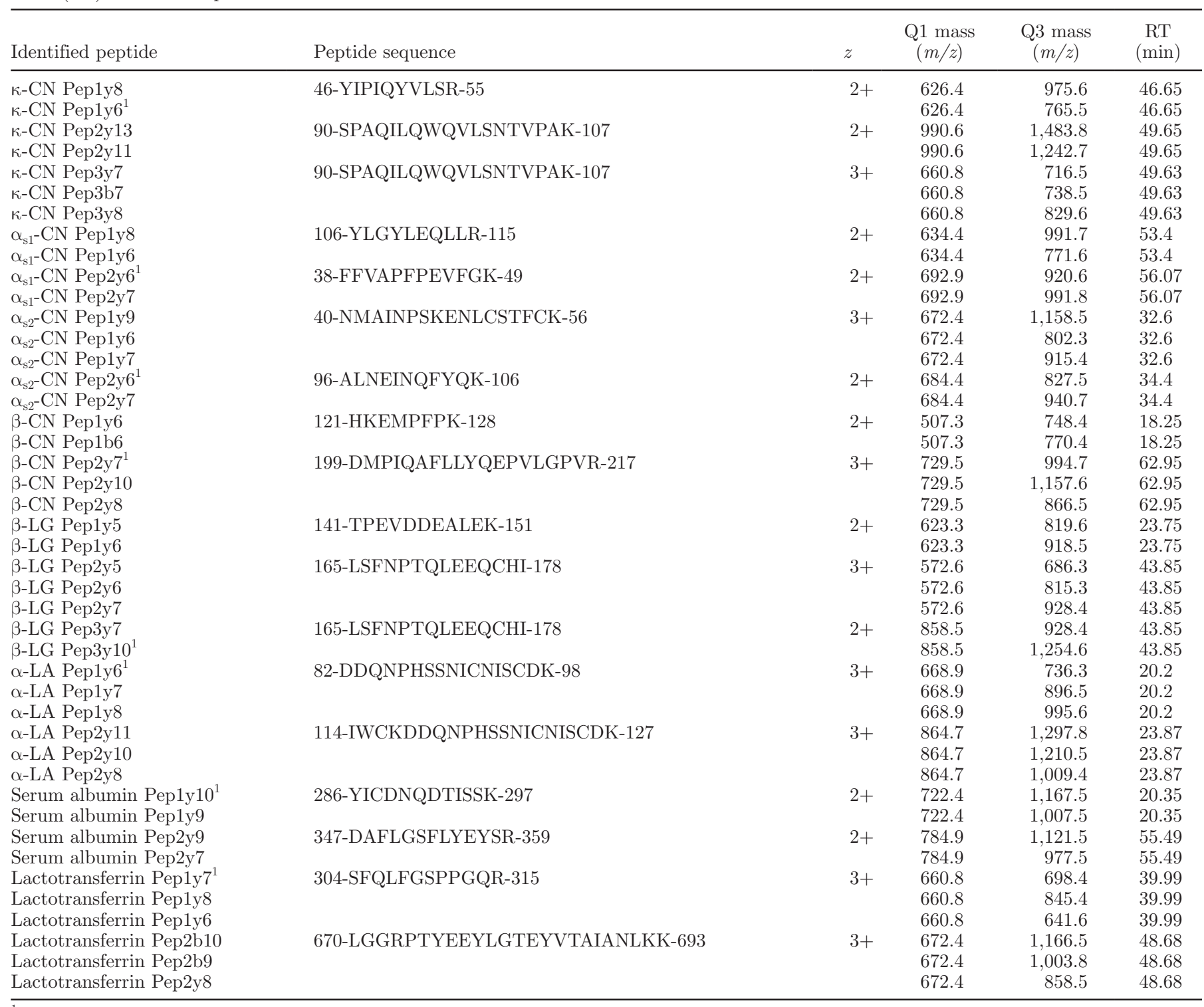

${ }^{1}$ Peptide with the highest response for the protein from which it was derived.

hydrophobic) interactions between the milk components and the membrane and (2) over time by deposition of foulants under the effect of transmembrane pressure.

An insight into the nature of the electrostatic interactions between milk components and the ceramic membrane can be gained by evaluating the zeta potential of both systems. Zeta potential of skim milk, evaluated over a wide $\mathrm{pH}$ range, was comparable with zeta potential values reported in literature for various milk proteins (Figure 6a). At the natural pH of milk (6.7), both the ceramic particles harvested from a new, unused membrane and skim milk were negatively charged. This suggests that the electrostatic interaction between skim milk and the membrane surface was repulsive and thus the skim milk components (most importantly, milk protein molecules) were expected to be repelled by the membrane material. Despite an overall negative charge, protein molecules have both negative and positive zones, which could allow localized contact between protein molecules and the membrane.

Most interestingly, the zeta-potential curve of ceramic particles obtained from a membrane that was repeatedly used and chemically cleaned was significantly different than the zeta-potential curve of the new membrane. The zeta potential of the used membrane became much closer to the zeta-potential curve of skim milk for the $\mathrm{pH}$ range 4.6 to 7.0 , whereas at lower $\mathrm{pH}$ values it virtually overlapped with the zeta potential 


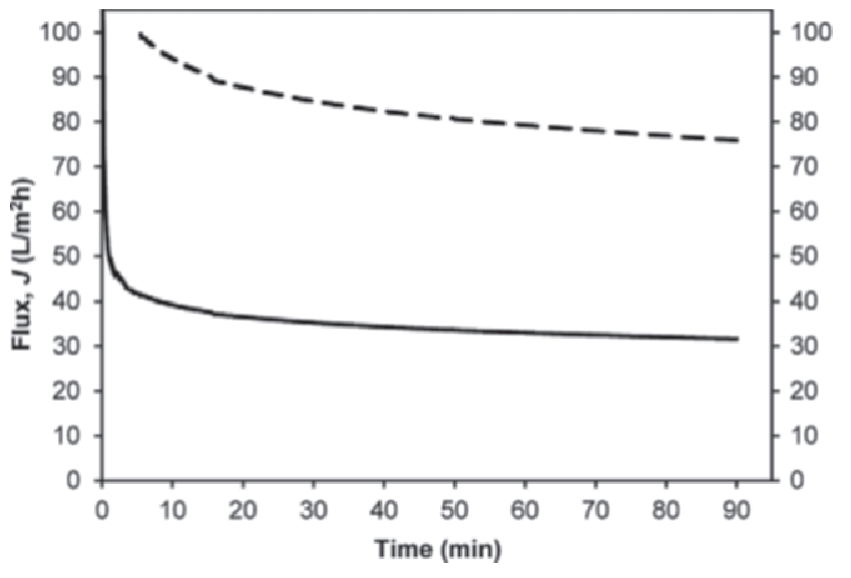

Figure 3. Example of the change in permeate flux ( $J$; solid curve) and flux decay $\left(J / J_{0}\right.$; dashed curve) during cold microfiltration of skim milk (data collected at a microfiltration run conducted at a membrane water flux of $1,219 \mathrm{~L} / \mathrm{m}^{2} \mathrm{~h}$ ).

of CN micelles reported by Bouzid et al. (2008; Figure $6 \mathrm{~b})$. This suggests that an irreversible fouling of the ceramic membrane with $\mathrm{CN}$ molecules occurred with time, which likely played a big role in the change of membrane properties and performance. It has been established before that proteins with a low internal stability (called soft proteins) tend to adsorb on all surfaces, irrespective of electrostatic interactions (Dickinson, 1999; Nakanishi et al., 2001). Many milk proteins, including $\beta$-CN, $\alpha-\mathrm{LA}, \mathrm{BSA}$, or immunoglobulin (IgG) are classified as soft proteins and as such can adsorb even onto electrostatically repelling surfaces (Dickinson, 1999).

Another membrane property that needs to be considered is its hydrophilic-hydrophobic character, because this is known to affect the strength of interaction between a protein and a surface. Specifically, proteins tend to adsorb more extensively and less reversibly at hydrophobic surfaces than at hydrophilic surfaces (Wang et al., 2012). According to existing literature, ceramic membranes are hydrophilic (Gao et al., 2011). The ceramic membranes used in this study were also hydrophilic, with a measured water contact angle of the active layer for the new, unused membrane of 62.2 $\pm 17.3^{\circ}$. The hydrophilic character of the membrane does not preclude the deposition of proteins onto its surface because whereas proteins tend to unfold and spread their hydrophobic core over hydrophobic surfaces, their charged and polar functional groups tend to interact with hydrophilic surfaces (Wang et al., 2012). In case of CN micelles, it is known that the hydrophilic ends of $\kappa$-CN molecules are preferentially located at the surface of micelles, which would explain the ceramic membrane- $\mathrm{CN}$ interactions. In this study, it was observed that the membrane became much more hydrophobic after repeated use, with a water contact angle of the active layer of $94.8 \pm 4.8^{\circ}$. This suggests an irreversible protein adsorption to the membrane, which also explains the decrease in the water flux of
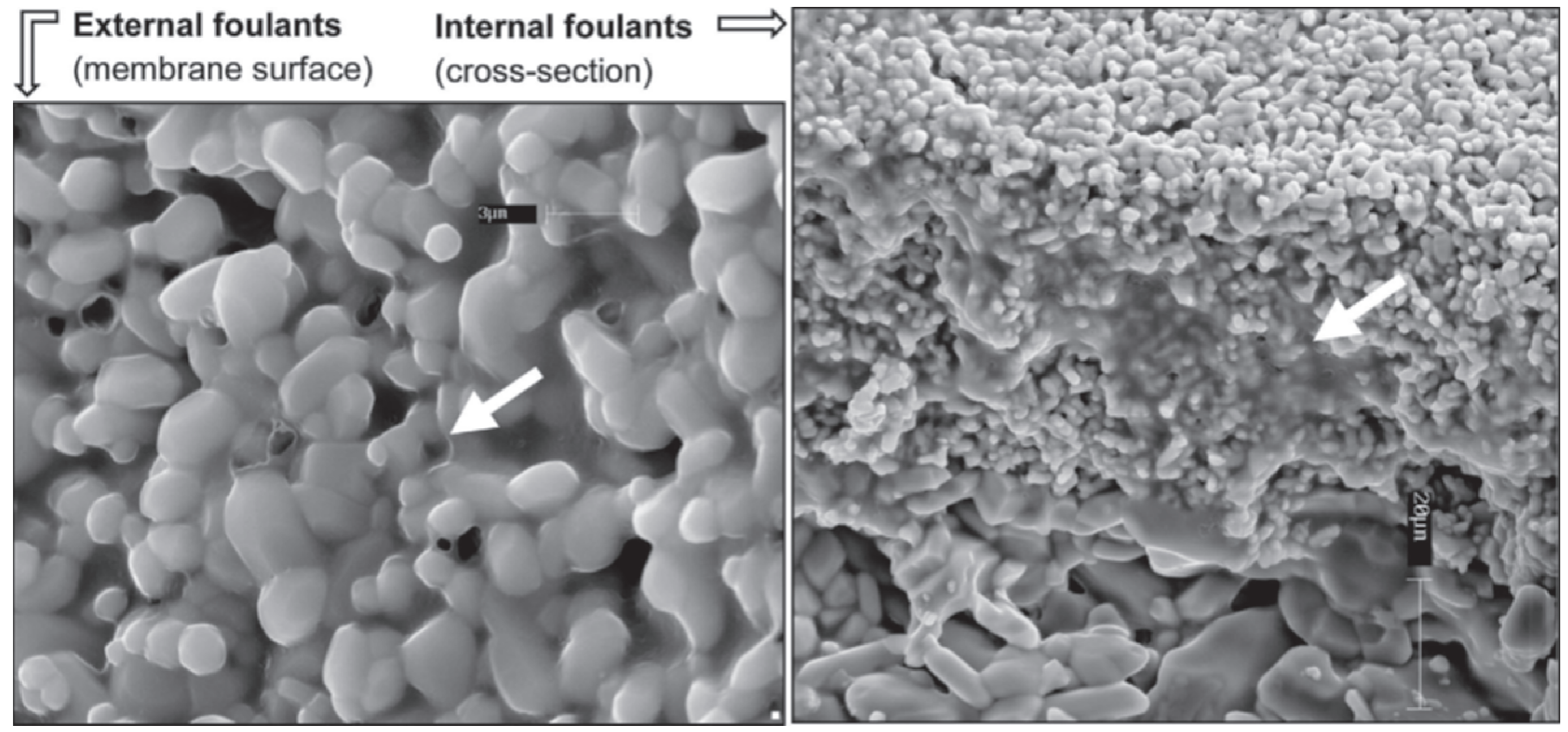

Figure 4. Scanning electron microscope images of the fouling layer (indicated by the white arrows) on the ceramic membrane surface (left) and within the internal structure (right). 


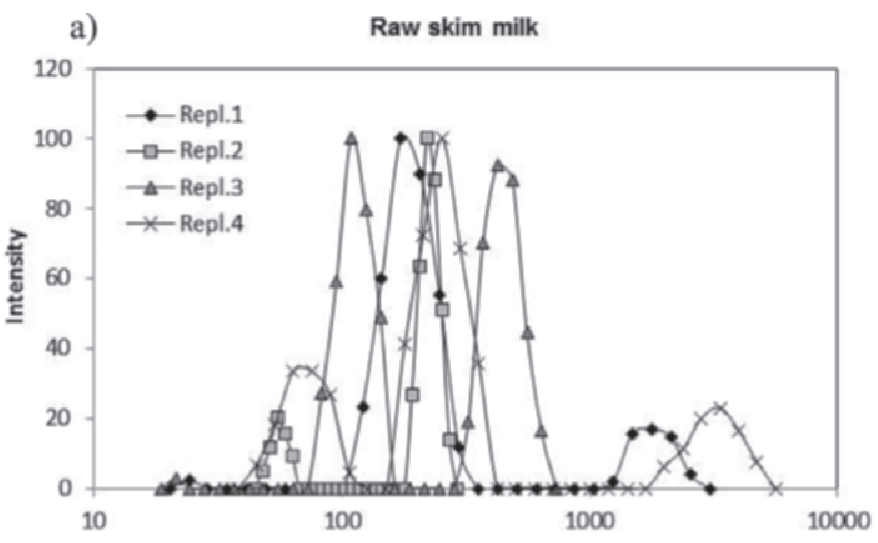

b) Membrane external fouling layer, removed by brushing

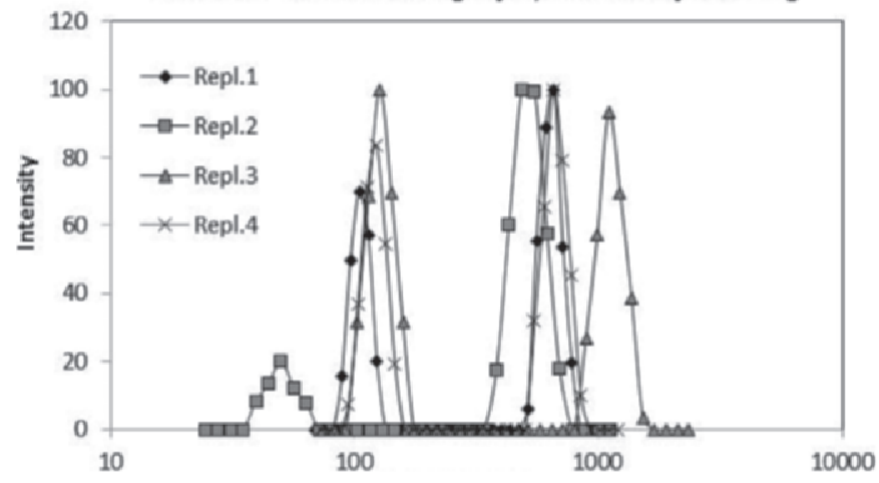

c)

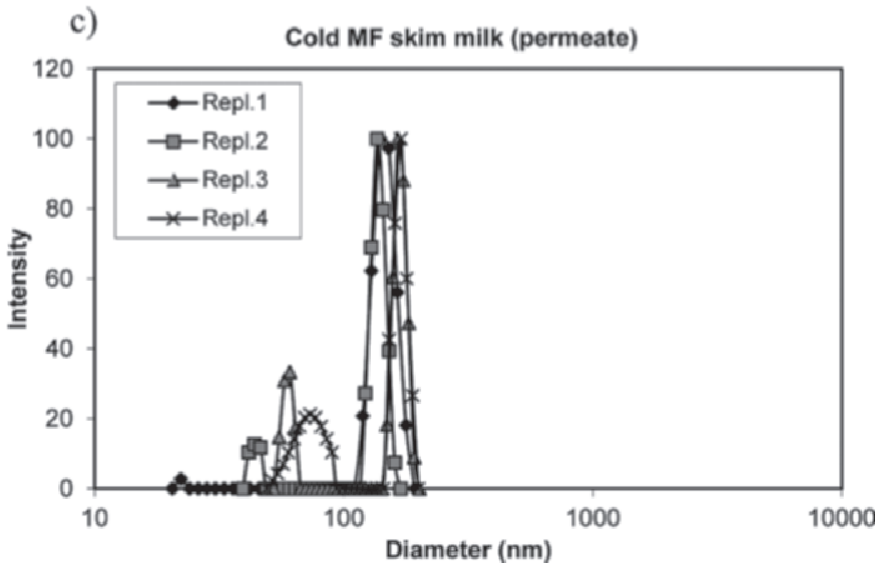

Figure 5. Particle-size distribution for (a) raw skim milk; (b) fouling material collected from the membrane surface; and (c) microfiltration (MF) skim milk (permeate). Repl. = replicate.

the membrane with time as reported by Fritsch and Moraru (2008).

The results presented above, corroborated with data from literature, suggest that the deposition of CN onto the membrane material plays a significant role in fouling in cold MF of skim milk. In the next section, this assumption is further substantiated using chemical analyses.

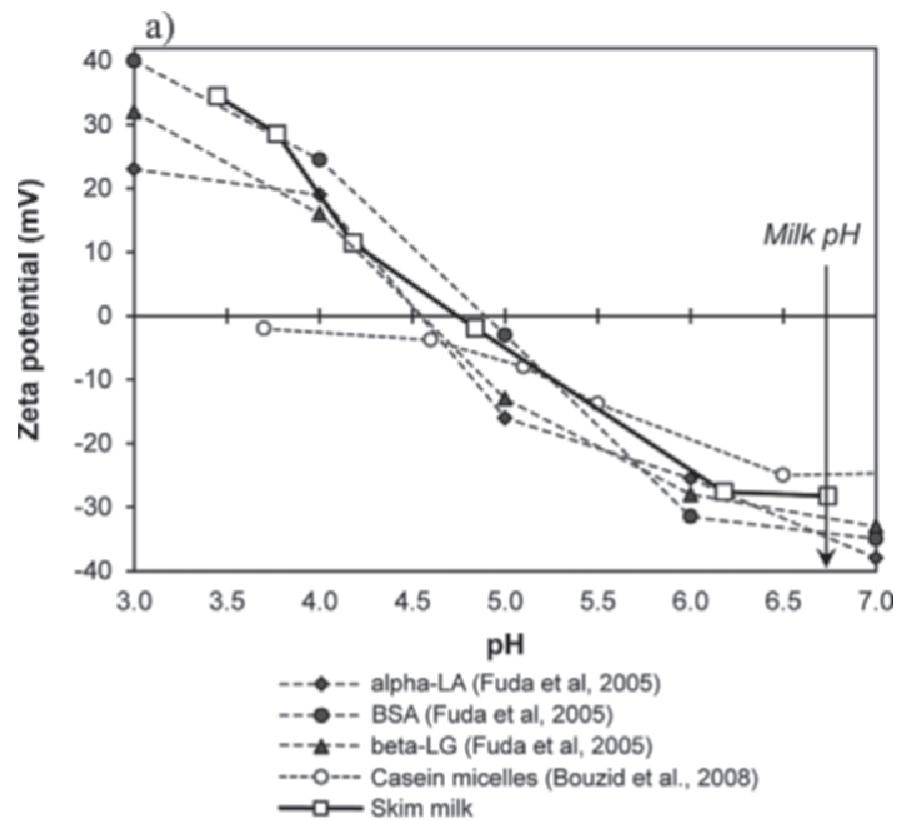

b)

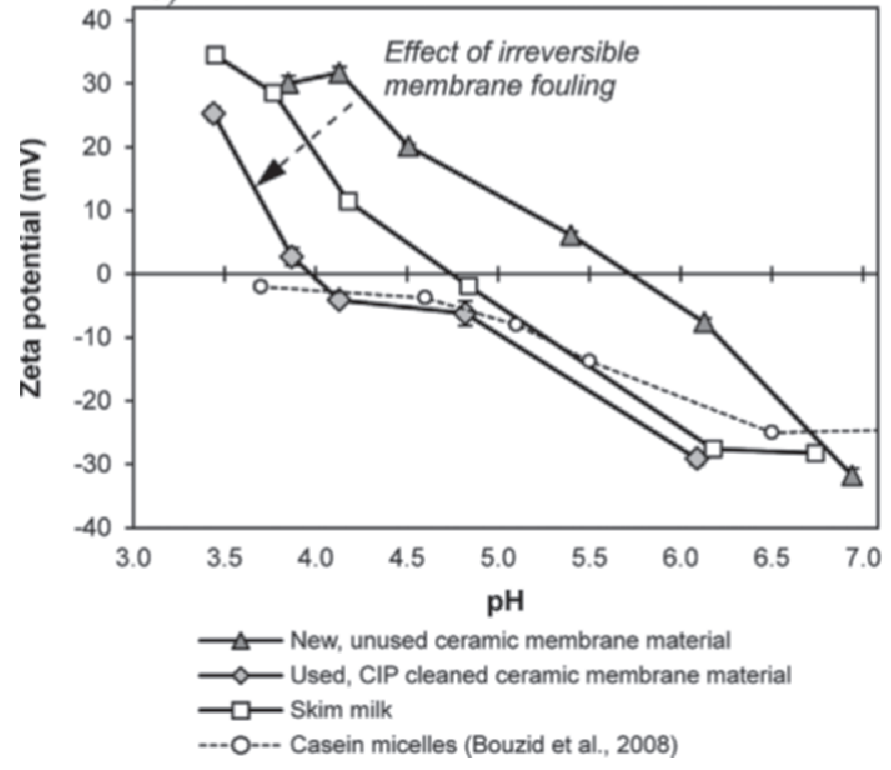

Figure 6. Zeta potential of (a) skim milk and milk components and (b) new and previously used membrane material, compared with select milk components. CIP $=$ cleaned-in-place.

\section{Chemical Evaluation of Membrane Fouling in Cold MF of Skim Milk}

Fouling by Proteins. To verify that the procedures used for collecting membrane foulants were able to fully extract all the protein foulants from the membrane, protein analyses were conducted for the alkaline cleaning solution that was used to chemically clean the membrane after foulant collection. No detectable level of protein was found in the alkaline cleaning solution, 
which suggests that most foulants were collected by RO water rinsing followed by pressurized hot water extraction.

Protein quantification in the foulant streams from the adsorption study demonstrates that proteins instantaneously attached to the membrane material, externally and internally, just by contact with milk, before MF took place (Figure 7). The protein concentration for the weakly attached external $\left(\mathrm{W}_{\mathrm{e}}\right)$, weakly attached internal $\left(\mathrm{W}_{\mathrm{i}}\right)$, and strongly attached external foulants $\left(\mathrm{S}_{\mathrm{e}}\right)$ were significantly higher for the foulants extracted after $90 \mathrm{~min}$ of MF as compared with the adsorption experiments, whereas the strongly attached internal foulants $\left(\mathrm{S}_{\mathrm{i}}\right)$ were comparable for the 2 situations. The amount of protein per active membrane area for the adsorption study was $0.51 \pm 0.11 \mathrm{~g} / \mathrm{m}^{2}, 0.21 \pm$ $0.08 \mathrm{~g} / \mathrm{m}^{2}, 0.09 \pm 0.01 \mathrm{~g} / \mathrm{m}^{2}$, and $0.07 \pm 0.03 \mathrm{~g} / \mathrm{m}^{2}$ for $\mathrm{W}_{\mathrm{e}}, \mathrm{W}_{\mathrm{i}}, \mathrm{S}_{\mathrm{e}}$, and $\mathrm{S}_{\mathrm{i}}$, respectively. By comparison, Tong et al. (1988) reported that the amount of protein per membrane area from the adsorption foulants in whole milk ultrafiltration was approximately $0.6 \mathrm{~g} / \mathrm{m}^{2}$. After $90 \mathrm{~min}$ of MF, these values were $3.55 \pm 0.58 \mathrm{~g} / \mathrm{m}^{2}, 0.61$ $\pm 0.05 \mathrm{~g} / \mathrm{m}^{2}, 0.38 \pm 0.04 \mathrm{~g} / \mathrm{m}^{2}$, and $0.06 \pm 0.01 \mathrm{~g} / \mathrm{m}^{2}$ for $\mathrm{W}_{\mathrm{e}}, \mathrm{W}_{\mathrm{i}}, \mathrm{S}_{\mathrm{e}}$, and $\mathrm{S}_{\mathrm{i}}$, respectively.

These data suggest that the protein foulants strongly attached to the internal structure of the membrane $\left(\mathrm{S}_{\mathrm{i}}\right)$ were trapped into the membrane structure mostly because of adsorption, with little influence of the transmembrane pressure. For all the other streams, fouling significantly increased during the actual MF process.

The proteins in the different foulant streams were then identified and relatively quantified (i.e., compared with the levels found in milk) by LC-MS/MS. As seen in Figure 8, all major milk proteins were present in all foulants collected from both the adsorption study and MF. Serum protein levels were higher as compared with their levels in milk in the weakly attached adsorption foulants, particularly in the $\mathrm{W}_{\mathrm{e}}$ fraction (Figure 8a). The only statistically significant difference as compared with milk was found for the $\alpha$-LA content in $W_{e}$, but $\beta-L G$ and BSA were also found in elevated levels in $\mathrm{W}_{\mathrm{e}}$. Caseins were found at the same levels as in milk. Opposite to this trend, all CN were found in a higher level than in milk in the foulants collected after $90 \mathrm{~min}$ of $\mathrm{MF}$, particularly in the $\mathrm{W}_{\mathrm{e}}, \mathrm{W}_{\mathrm{i}}$, and $\mathrm{S}_{\mathrm{e}}$ fractions.

This suggests a higher affinity of the major serum proteins ( $\alpha-\mathrm{LA}, \beta-\mathrm{LG}$, and BSA) for the membrane material, which may be due both to their smaller molecular size as compared with CN micelles and possibly to being less hydrophobic than CN. Caseins, on the other hand, were mostly introduced into the fouling layer when transmembrane pressure was applied. The fact that most $\mathrm{CN}$ were found at the highest levels in the $S_{e}$ fraction indicates an irreversible binding of CN to the membrane surface. This explains the observed changes in the zeta-potential curve and increase in hydrophobicity of the membrane surface discussed in the previous section.

Fouling by Minerals. Minerals identified in the foulant streams were calcium $(\mathrm{Ca})$, phosphorus $(\mathrm{P})$, magnesium $(\mathrm{Mg})$, potassium $(\mathrm{K})$, sodium $(\mathrm{Na})$, and chlorine $(\mathrm{Cl})$. The mineral composition of the water used for foulant extraction and of the skim milk used in the experiments is shown in Table 2, and the mineral composition of the 4 foulant streams from both adsorption and MF is shown in Figure 9. The contribution of the extraction water to the mineral content of the foulants was negligible except for $\mathrm{Cl}$, which has been excluded from the discussion because of high levels in the extraction water.

Overall, the mineral concentrations were very small in all foulant streams, below $2.5 \mu \mathrm{g} / \mathrm{mL}$, and likely do not play a major role in the membrane fouling in cold MF. It is worth noting though that the $\mathrm{Ca}$ and $\mathrm{P}$ concentrations in the $\mathrm{W}_{\mathrm{e}}, \mathrm{W}_{\mathrm{i}}$, and $\mathrm{S}_{\mathrm{e}}$ fractions from $\mathrm{MF}$ were significantly higher than in the respective foulant fractions from adsorption. This is in agreement with the increased $\mathrm{CN}$ levels in the foulant streams from $\mathrm{MF}$, because much of the $\mathrm{Ca}$ and $\mathrm{P}$ in milk are associated with the CN micelle (Lucey and Horne, 2009).

It should be noted that extraction with hot water could have resulted in some precipitation of the calcium phosphate present in the fouling layer onto the membrane, thus lowering the amount of Ca identified in the strongly attached foulants. Nonetheless, a calculation of the ratio between the minerals found in the different

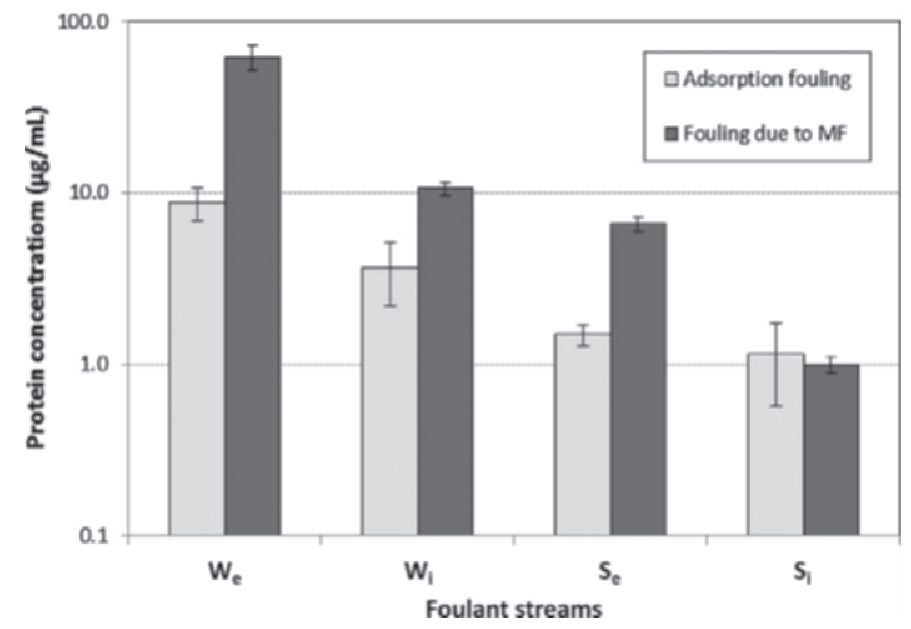

Figure 7. Protein concentrations of foulant streams from adsorption and control microfiltration (MF). Error bars represent one standard deviation $(\mathrm{n}=3)$. $\mathrm{W}_{\mathrm{e}}$ = weakly attached external foulants; $\mathrm{W}_{\mathrm{i}}$ = weakly attached internal foulants; $\mathrm{S}_{\mathrm{e}}=$ strongly attached external foulants; $\mathrm{S}_{\mathrm{i}}=$ strongly attached internal foulants. 

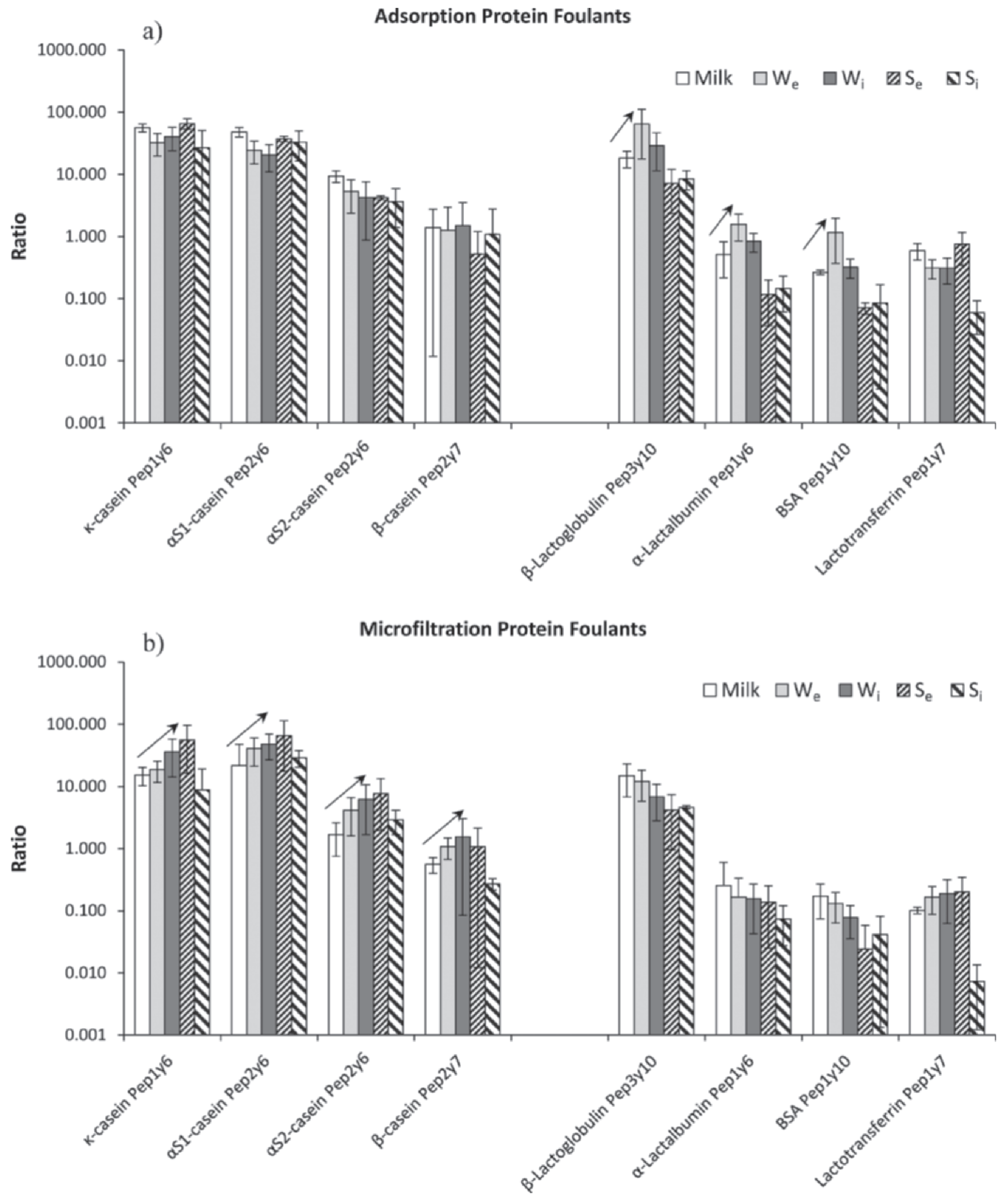

Figure 8. Ratio of milk proteins identified in the fouling material extracted from the ceramic membrane after (a) adsorption and (b) microfiltration. Error bars represent one standard deviation $(\mathrm{n}=3) . \mathrm{W}_{\mathrm{e}}=$ weakly attached external foulants; $\mathrm{W}_{\mathrm{i}}=$ weakly attached internal foulants; $\mathrm{S}_{\mathrm{e}}=$ strongly attached external foulants; $\mathrm{S}_{\mathrm{i}}=$ strongly attached internal foulants. 
Table 2. Mineral composition (total mineral content) of the reverseosmosis water used for extraction of foulants and of the skim milk used in the adsorption and microfiltration experiments

\begin{tabular}{lcc}
\hline Mineral & $\begin{array}{c}\text { Concentration } \\
\text { in the extraction } \\
\text { water }(\mu \mathrm{g} / \mathrm{mL})\end{array}$ & $\begin{array}{c}\text { Concentration } \\
\text { in milk }(\mu \mathrm{g} / \mathrm{mL})\end{array}$ \\
\hline $\mathrm{Ca}$ & $0.05 \pm 0.03$ & $1,108 \pm 17$ \\
$\mathrm{P}$ & $0.01 \pm 0.00$ & $957 \pm 26$ \\
$\mathrm{Mg}$ & $0.02 \pm 0.00$ & $102 \pm 6$ \\
$\mathrm{~K}$ & $0.01 \pm 0.00$ & $1,519 \pm 22$ \\
$\mathrm{Na}$ & $0.17 \pm 0.03$ & $379 \pm 27$ \\
\hline
\end{tabular}

foulant streams did not show a lower concentration of $\mathrm{Ca}$ in the strongly attached foulants compared with the weakly attached foulants. Moreover, even if some precipitation of minerals did occur during the hot extraction, this is not expected to change the conclusions of this study because MF was conducted at low temperatures, where fouling by mineral precipitation is unlikely.

\section{CONCLUSIONS}

Fouling in cold, large-pore MF of skim milk was primarily caused by milk proteins. Whereas serum proteins seem to preferentially adsorb onto the ceramic membrane surface upon contact, $\mathrm{CN}$ are introduced into the fouling layer by the application of transmembrane pressure. Fouling by $\mathrm{CN}$ did lead to some irreversible, permanent changes of the membrane surface properties, which changes membrane performance over time. The results of this study help in the understanding of fouling mechanisms in MF of skim milk at low temperatures and can be used as a basis for developing solutions to minimize membrane fouling and thus increase product yields during membrane filtration of milk.

\section{ACKNOWLEDGMENTS}

This study was supported with funds from the New York State Milk Promotion Board (Albany, NY). Author Tan acknowledges the financial support received for his doctoral studies from the Ministry of Higher Education Malaysia and the International Dairy Foods Association. The authors thank Julia Fritsch for conducting the scanning electron microscope imaging experiments, Yifan Cheng for the water contact-angle measurements, and Cosmin Beliciu for his assistance with the particle-size and zeta-potential analyses.

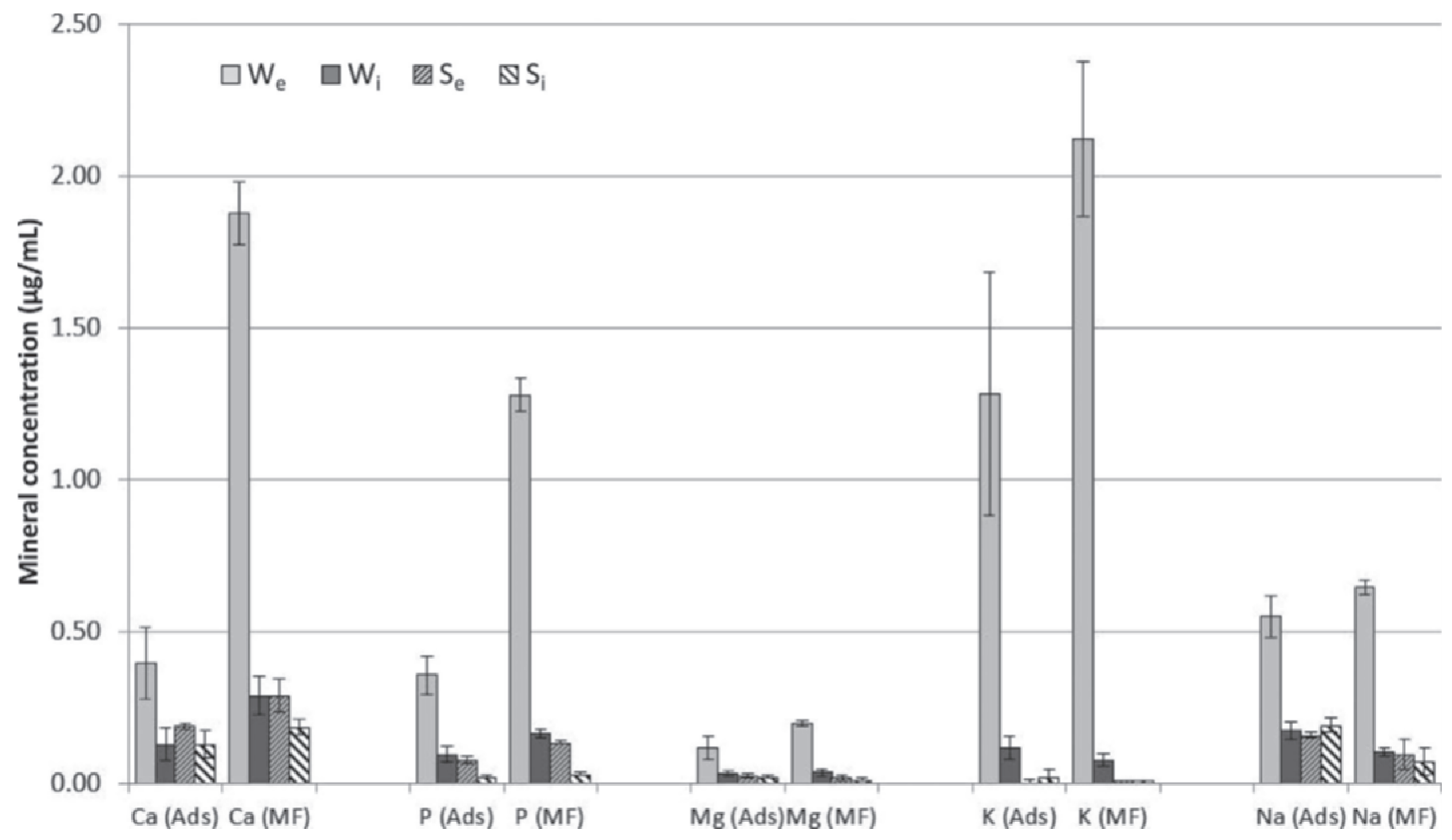

Figure 9. Mineral concentrations in the foulant streams from adsorption (Ads) and microfiltration (MF). Error bars represent one standard deviation $(\mathrm{n}=3)$. $\mathrm{W}_{\mathrm{i}}=$ weakly attached internal foulants; $\mathrm{S}_{\mathrm{e}}=$ strongly attached external foulants; $\mathrm{S}_{\mathrm{i}}=$ strongly attached internal foulants. 


\section{REFERENCES}

Anderson, P. J., C. L. Brooks, and L. J. Berliner. 1997. Functional identification of calcium binding residues in bovine $\alpha$-lactalbumin. Biochemistry 36:11648-11654.

Azzara, C. D., and P. S. Dimick. 1985. Lipoprotein lipase activity of milk from cows with prolonged subclinical mastitis. J. Dairy Sci. 68:3171-3175.

Beliciu, C. M., and C. I. Moraru. 2009. Effect of solvent and temperature on the size distribution of casein micelles measured by dynamic light scattering. J. Dairy Sci. 92:1829-1839.

Blanpain-Avet, P., C. Faille, G. Delaplace, and T. Bénézech. 2011. Cell adhesion and related fouling mechanism on a tubular ceramic microfiltration membrane using bacillus cereus spores. J. Membr. Sci. 385-386:200-216.

Bouzid, H., M. Rabiller-Baudry, L. Paugam, F. Rousseau, Z. Derriche, and N. E. Bettahard. 2008. Impact of zeta potential and size of caseins as precursors of fouling deposit on limiting and critical fluxes in spiral ultrafiltration of modified skim milks. J. Membr. Sci. 314:67-75.

Bradford, M. M. 1976. A rapid and sensitive method for the quantitation of microgram quantities of protein utilizing the principle of protein-dye binding. Anal. Biochem. 72:248-254.

Brans, G., C. G. P. H. Schroën, R. G. M. van der Sman, and R. M. Boom. 2004. Membrane fractionation of milk: State of the art and challenges. J. Membr. Sci. 243:263-272.

Dickinson, E. 1999. Adsorbed protein layers at fluid interfaces: Interactions, structure and surface rheology. Colloids Surf. B Biointerfaces 15:161-176.

Ebhardt, H. A., E. Sabidó, R. Hüttenhain, B. Collins, and R. Aebersold. 2012. Range of protein detection by selected/multiple reaction monitoring mass spectrometry in an unfractionated human cell culture lysate. Proteomics 12:1185-1193.

Fane, A. G., and S. Chang. 2009. Techniques to enhance performance of membrane processes. Pages 193-232 in Handbook of Membrane Separations: Chemical, Pharmaceutical, Food, and Biotechnological Applications. A. K. Pabby, S. S. H. Rizvi, and A. M. Sastre, ed. CRC Press, Boca Raton, FL.

Fritsch, J., and C. I. Moraru. 2008. Development and optimization of a carbon dioxide-aided cold microfiltration process for the physical removal of microorganisms and somatic cells from skim milk. J. Dairy Sci. 91:3744-3760.

Fuda, E., D. Bhatia, D. L. Pyle, and P. Jauregi. 2005. Selective separation of beta-lactoglobulin from sweet whey using CGAs generated from the cationic surfactant CTAB. Biotechnol. Bioeng. 90:532-542.

Gao, N., M. Li, W. Jing, Y. Fan, and N. Xu. 2011. Improving the filtration performance of $\mathrm{ZrO} 2$ membrane in non-polar organic solvents by surface hydrophobic modification. J. Membr. Sci. 375:276-283.

Gesan, G., G. Daufin, U. Merin, J. P. Labbe, and A. Quemriais. 1993. Fouling during constant flux crossflow microfiltration of pretreated whey: Influence of transmembrane pressure gradient. J. Membr. Sci. 80:131-145.

Gesan-Guiziou, G. 2010. Removal of bacteria, spores and somatic cells from milk by centrifugation and microfiltration techniques. Pages 349-372 in Improving the Safety and Quality of Milk. Vol. 1: Milk production and processing. M. W. Griffiths, ed. Woodhead Publishing Ltd., Cambridge, UK.
Guerra, A., G. Jonsson, A. Rasmussen, E. Waagner Nielsen, and D. Edelsten. 1997. Low cross-flow velocity microfiltration of skim milk for removal of bacterial spores. Int. Dairy J. 7:849-861.

Hanemaaijer, J. H., T. Robbertsen, T. van den Boomgaard, and J. W. Gunnink. 1989. Fouling of ultrafiltration membranes-The role of protein adsorption and salt precipitation. J. Membr. Sci. 40:199-217.

James, B. J., Y. Jing, and X. Dong Chen. 2003. Membrane fouling during filtration of milk-A microstructural study. J. Food Eng. 60:431-437.

Kelly, S. T., and A. L. Zydney. 1997. Protein fouling during microfiltration: Comparative behavior of different model proteins. Biotechnol. Bioeng. 55:91-100.

Le Berre, O., and G. Daufin. 1998. Microfiltration $(0.1 \mu \mathrm{m})$ of milk: Effect of protein size and charge. J. Dairy Res. 65:443.

Lucey, J. A., and D. S. Horne. 2009. Milk salts: Technological significance. Pages 351-389 in Advanced Dairy Chemistry: Lactose, Water, Salts and Minor Constituents. Vol. 3. 3rd ed. P. L. H. McSweeney and P. F. Fox, ed. Springer, New York, NY.

Ma, Y. C. Ryan, D. M. Barbano, D. M. Galton, M. A. Rudan, and K. J. Boor. 2000. Effects of somatic cell count on quality and shelf-life of pasteurized fluid milk. J. Dairy Sci. 83:264-274.

Mourouzidis-Mourouzis, S. A., and A. J. Karabelas. 2006. Whey protein fouling of microfiltration ceramic membranes-Pressure effects. J. Membr. Sci. 282:124-132.

Nakanishi, K., T. Sakiyama, and K. Imamura. 2001. On the adsorption of proteins on solid surfaces, a common but very complicated phenomenon. J. Biosci. Bioeng. 91:233-244.

O'Donnell, R., J. W. Holland, H. C. Deeth, and P. Alewood. 2004. Milk proteomics. Int. Dairy J. 14:1013-1023.

Picotti, P., B. Bodenmiller, and R. Aebersold. 2013. Proteomics meets the scientific method. Nat. Methods 10:24-27.

Rice, G., A. Barber, A. O'Conner, G. Stevens, and S. Kentish. 2009 Fouling of NF membranes by dairy ultrafiltration permeates. J. Membr. Sci. 330:117-126.

Saboya, L. V., and J.-L. Maubois. 2000. Current developments of microfiltration technology in the dairy industry. Lait 80:541-553.

Sauer, A., and C. I. Moraru. 2012. Heat stability of micellar casein concentrates as affected by temperature and $\mathrm{pH}$. J. Dairy Sci. 95:6339-6350.

Stuart, D. I., K. R. Archaya, N. P. C. Walker, S. G. Smith, M. Lewis, and D. C. Phillips. 1986. $\alpha$-Lactalbumin possesses a novel calcium binding loop. Nature 324:84-87.

Te Giffel, M. C., and H. C. Van der Horst. 2004. Comparison between bactofugation and microfiltration regarding efficiency of somatic cell and bacteria removal. Bull. Int. Dairy Fed. 389:49-53.

Tong, P. S., D. M. Barbano, and M. A. Rudan. 1988. Characterization of proteinaceous membrane foulants and flux decline during the early stages of whole milk ultrafiltration. J. Dairy Sci. 71:604-612.

Verdi, R. J., and D. M. Barbano. 1988. Preliminary investigation of the properties of somatic cell proteases. J. Dairy Sci. 71:534-538.

Wang, K., C. Zhou, Y. Hong, and X. Zhang. 2012. A review of protein adsorption on bioceramics. Interface Focus 2:259-277.

Zhang, S., R. W. Sherwood, Y. Yang, T. Fish, W. Chen, J. A. McCardle, R. M. Jones, V. Yusibov, E. R. May, J. K. C. Rose, and T. W. Thannhauser. 2012. Comparative characterization of the glycosylation profiles of an influenza hemagglutinin produced in plant and insect hosts. Proteomics 12:1269-1288 